\title{
Legenavn og talegjenkjenning
}

\author{
Har du fått navnet ditt forvrengt av talegjenkjenningsprogrammer? Da er ikke du den eneste.
}

Det norske språk er levende og endres over tid. Leser man en 30-40 år gammel tekst, virker ofte språkbruken formell og unaturlig. At språket vårt endrer seg og gjenspeiler tidsepoken man lever i, er ikke nødvendigvis noe negativt. Mange spådde både gramma-

\section{«dr. Megavatt Avvik»}

tikk og rettskrivning en snarlig død da SMSspråket dukket opp, men disse profetiene ser heldigvis ikke ut til å ha gått i oppfyllelse. SMS-språket fremstår nå som et fargerikt tilskudd til skriftspråket, der man stadig blir forbløffet over ungdommens kreativitet til å korte ned ord og uttrykk.

Det er nå kommet et nytt teknologisk hjelpemiddel som vil påvirke skriftspråket vårt i årene fremover - talegjenkjenning (1). Mange har sterke meninger om dette redskapet, men enten man liker eller hater det, vil det komme til å bli en del av vår hverdag.

\section{Gjenkjenning}

Talegjenkjenning bygger på relativt kompliserte algoritmer. Når dataprogrammet skal velge ordet som skal dukke opp på skjermen, baserer det seg på en ordliste som interagerer med statistikk for hvor ofte

\section{«dr. Borer Tykktarm»}

ordet blir brukt og sannsynligheten for at det skal opptre i den aktuelle ordrekken. Dataprogrammet skal også være tilpasningsdyktig og lage en «profil» som skal gjøre programmet stadig bedre i stand til å gjette hvilke formuleringer den aktuelle brukeren pleier å benytte.

I teorien er dette vel og bra. Men når man har brukt talegjenkjenning en stund, finner man ut at enkelte setninger gjenkjennes greit nok, mens andre aldri blir gjenkjent uansett hvor mange ganger man fors $\varnothing$ ker å rette og «lære opp» profilen sin. Etter en stund gir man opp, og istedenfor at programmet tilpasser seg brukeren, tilpasser brukeren seg programmet og endrer språkbruken til formuleringer som han eller hun vet blir gjenkjent (2).
Et annet aspekt som mange sikkert har lagt merke til, er at egennavn ikke er talegjenkjenningens sterkeste side. Når man dikterer navnet på kollegene sine, må man ofte trekke på smilebåndet.

\section{Pilot}

Undertegnede deltok i pilotprosjektet for innføring av talegjenkjenning ved Haraldsplass Diakonale Sykehus i Bergen. Her ble jeg noe overrasket over legestabsoversikten som programmet fra Max Manus har. Noen blir faktisk gjenkjent med riktig navn, deriblant klinikksjefen, så man kan jo stille spørsmål ved om det har foregått en lobbyvirksomhet i kulissene for å komme inn i ordlisten. Ikke alle er like morsomme, men det er definitivt noen gullkorn, som

\section{«dr. I Bunnen Bevisstløs»}

dr. Megavatt Avvik, dr. Borer Tykktarm og dr. I Bunnen Bevisstløs. I tillegg var det betryggende å få vite at vår kollega Lorentz er vanlig under.

Under følger den komplette listen over leger ved Medisinsk avdeling ved Haraldplass Diakonale Sykehus i henhold til Max Manus da vi skulle innføre talegjenkjenning:

Dr. Ikke Relatere Vil (dr. Michaela Thierley) Dr. R Skulle Han (dr. Odny Askeland) Dr. Marit Nakken (dr. Marit Bakken) Dr. Gjorde En Rekke (dr. Jorunn Brekke) Dr. F. Fremmedlyder (dr. Efraim Bulut) Dr. Juli Akse Som (dr. Julia Chelsom) Dr. Samme Dag Som (dr. Cedric Davidsen) Dr. Blitt Lenger (dr. Britt Engan)

Dr. Steiner Med Grader (dr. Stein Arne Gravdal)

Dr. For Rikelig (dr. Alf-Olav Haukelid)

Dr. Overblikk Hope (dr. Håvar Blich Hope)

Dr. 8 Og Hope (dr. Ottar Hope)

Dr. Geir Følger Landet (dr. Geir Hølleland)

Dr. Elisabeth Iversen (dr. Elisabeth Iversen)

Dr. Man Kan Kanskje (dr. Iman Karaji)

Dr. Crista Urin (dr. Christer Lie)

Dr. Frode Lengde Mark (dr. Frode Lindemark)

Dr. Melena Markova (dr. Elena Markova)

Dr. Måler Men Ikke Inneholder

(dr. Mala Naik)
Dr. Stabil Med Typen Stokk Morgen (dr. Sabine Piepenstock Nore)

Dr. Pollen og Sønn (dr. Paal Naalsund)

Dr. Rolf Pedersen (dr. Rolf Pedersen)

Dr. 60 Piller Bergen (dr. Kjersti Pileberg)

Dr. Er Inndratt (dr. Eivind Rath)

Dr. I Bunnen Bevisstløs (dr. Idunn Riisnes)

Dr. Denne Tilstanden I Kneet (dr. Kenneth Sandviknes)

Dr. Maria CRP Og Hvite (dr. Maria Seferowics)

Dr. Anne Britt Skjerpet (dr. Anne-Britt Skjærpe)

Dr. M Speil I Hauger (dr. Ole Martin Steihaug)

Dr. Cheyne-Stokes (dr. Charlotte Stokes)

Dr. Svar Og Man Tilfører (dr. Solomon Tefera)

Dr. Erik Thomassen (dr. Erik Thomassen)

Dr. Britt Undheim (dr. Britt Undheim)

Dr. Megawatt Avvik (dr. Vegard Vavik)

Dr. Chronica Var Det (dr. Veronika Varga)

Dr. Ingen Har Det Hele Ellingsen

(dr. Ingvard Wilhelmsen)

Dr. Nokså Han Er Eser Ut (dr. Oxana Ezau)

Dr. Lorentz Er Vanlig Under (dr. Lorentz

Erland Linde)

Dr. M Pilskog (dr. Martin Pilskog)

Dr. Av Dette Er En Haug (dr. Anette Raunehaug)

Dr. Stigende Cirka Svein Ligger

(dr. Stine Kirkholm Sveinegard)

Dr. Borer Tykktarm (dr. Bård Kittang)

\section{Cedric Davidsen}

cdavidsen@gmail.com

Hjerteavdelingen

Haukeland universitetssykehus

Cedric Davidsen (f. 1980) er lege i spesialisering ved Hjerteavdelingen, Haukeland universitetssykehus.

\section{Litteratur}

1. Max Manus. Talegjenkjenning og digital diktering. http://maxmanus.no/ (27.2.2013)

2. Wyller TB. Hvor stort gjennomslag har en medisinsk ordbok? Tidsskr Nor Legeforen 2010; 130 . 655 .

Mottatt 24.2.2013 og godkjent 27.2. 2013. Medisinsk redaktør Raida Ødegaard. 